\title{
Gulf-China relations, the belt and road initiative and its impact on Gulf security
}

\author{
Basma Khaleel Namuq ${ }^{\#}$ and Dr. Mohamed Aziz Abdul-Hassan^^${ }^{*}$ \\ \#Assistant Professor College of Political Science, University of Baghdad research field: international studies. Al - Jadriya Complex, Baghdad, Iraq \\ $\wedge$ Assistant Professor Al-Bayati College of Political Science, University of Baghdad research field: international studies. Al - Jadriya Complex, Baghdad, \\ Iraq
}

Received 10 April 2019, Accepted 12 June 2019, Available online 13 June 2019, Vol.7 (May/June 2019 issue)

\begin{abstract}
The Gulf Cooperation Council of China is based on the idea of replacing the Gulf with the axis of its relations and its previous alliances with America and the West with a new one. It is a strategy that links and strengthens its old alliances and alliances with new ones, while attracting the Chinese side's project towards the Gulf and reducing its dependence on the Asian road
\end{abstract}

Keywords: Gulf-China relations, belt and road initiative impact Gulf security

\section{Research importance}

${ }^{1}$ The establishment of the parties to the region for its international relations and its relations with the world powers is undoubtedly an important, fundamental and central issue in regional security and national security at all levels.

This issue seriously affects the security of each country and in a reciprocal manner among them. Events and developments in the conflict in the region

In early July of this year (2018), Chinese President Xi Jinping, accompanied by a large Chinese delegation, visited Kuwait and announced the establishment of a strategic partnership with Kuwait, which included understanding of a distinguished role for Kuwait in China's Great Strategic Project (Belt and Belt Initiative) and Road Initiative) and revive the Silk Road. On July 21, 2018, a strategic partnership agreement was signed between China and the United Arab Emirates (UAE) after the Chinese President was warmly received in Abu Dhabi. In light of the series of these meetings and these declarations comes to the mind of the researcher and interested in international and regional affairs the following

Will the invocation of China and the development of relations with it be a factor of balance, calm and stability in the region or a fueling and complication of international conflicts in light of the growing economic conflict between China and America?

This is a question that will be the focus of our research, from which we will embark on a realistic

*Corresponding author's ORCID ID: 0000-0000-0000-0000

DOI: https://doi.org/10.14741/ijmcr/v.7.3.13 hypothesis: that despite the view of every international pole of its interests and security accounts in the first place and the employment of its relations in its service, the emergence of China in the regional scene alongside the Gulf side (known for its caution and rationality) Will undoubtedly contribute to the service of security

1. The Gulf Cooperation Council (GCC): It is the main station to revive the ancient Silk Road linking the continents of Asia and Europe?

The importance of the strategic relations between the Gulf States and China will become more important under the Beijing Road and Road Initiative in 2013 to revive the ancient Silk Road connecting the continents of Asia, Europe and Africa to enhance cooperation and increase development among the road belt countries, Gulf Cooperation Council is one of its most important stations Despite the mutual advantages and benefits of the relations between the two sides, the establishment of a strategic partnership between the two sides is far from attainable and difficult to predict for the nature of China's foreign policy, its goals and premises, and the historical legacy of Chinese thinking towards the Gulf region in particular and the world in general except for China's neighboring countries On Chinese security.

China is keen to build broad relations in the Middle East, specifically with the UAE and Saudi Arabia.

There are several other reasons other than oil and gas for China to move to the Arabian Gulf.

Land Shipping Costs and Shipping Compared to shipping, China is pushing for greater reliance on sea freight through Arab waters, especially in the waters of the Arabian Gulf 
China is looking strategically into the Arabian Gulf, especially towards Saudi Arabia and the UAE, as a strategic alternative to Iran

Iran's fragile internal situation, which is witnessing an upsurge in protests and elements of a social revolution, or separatist movements in the national territories, which could make Iran a new armed conflict zone that threatens Chinese interests

China agrees with all the research and studies conducted by the Western and Chinese research centers on the limited Iranian role in the Asia region

Iran is not an influential player in Central Asia, nor is it capable of being a Chinese agent. It is confined to Iranian geography and its immediate surroundings (perhaps Afghanistan, northern Iraq and some parts of Syria which reduces the strategic value of the Iranian regime that is trying to promote it. Especially that the role of Iran in Central Asia is witnessing several obstacles, notably US, Russian and Chinese rivalry in Central Asia.

The Central Asian countries (Sunnis except Tajikistan) are concerned about Iran's ideological influence

The volume of trade and the intra-Iranian interests of these countries are very limited unstable regional relations with Azerbaijan to the north, Afghanistan to the east, and the Arab world to the west.

2. Oil and gas from the Gulf countries account for onethird of China's consumption. China's import of Gulf Arab oil is expected to triple the US imports from it in 2025 ? Middle East energy supplies are one of the most vital issues in China's direction, with Arab oil and gas accounting for one-third of China's consumption, and China's import of Gulf oil is expected to triple three times US imports in 2025. China has no oil reserves Emergency strategy for more than 16 days (in the case of losing $5 \%$ of its oil imports only, the reserve will end in 9 months.

There are several advantages of the Gulf to push China to revive the Silk Road and make the Gulf Cooperation Council countries a major party, including the following:

First: the Gulf consumer market for the Chinese product Of goods, tools, services, heavy industries and Chinese technology

\section{Second: Political stability of the GCC regimes}

Third: a large, completed infrastructure capable of being an advanced logistic supporter of the Chinese project (unlike Iran's rival with dilapidated infrastructure, if any.

Fourthly, China is seriously considering the geopolitical, economic and military value of the Arabian Sea and Red Sea watersheds as the linchpin of the sea route, which is the least costly, political, safest, and most costeffective (the maximum load of the China Railway does not exceed 200 containers, And the cost of shipping is $25 \%$ lower than the cost of land transport.
Fifth: $15 \%$ of China's total oil imports from Saudi Arabia. The inter-trade volume reached 69 billion dollars in early 2016.

Joint ties with the Chinese president's visit to Saudi Arabia were strengthened in January 2016, followed by King Salman's visit to China in March 2017.

The two countries have signed several economic and strategic partnership agreements over the past few years, most notably a joint memorandum of understanding on the economic belt of the Silk Road and the Silk Road Initiative.

The passage of the sea-to-sea sea silk route is important for the western ports of Saudi Arabia, which may at least double the vessels crossing the Red Sea. The Saudi Crown Prince has already stated that Saudi Arabia does not currently benefit from its ports on the Red Sea sufficiently, and that operating these ports is one of Saudi Arabia's plans within the 2030 vision.

Conclusion

The Silk Road is historically linked to the Arabs. Two thousand years ago, the geographical location of the Arab countries played a pivotal role as a link between Asia, Europe and Africa, and China's Xinjiang region was the gateway to the Muslim world.

In 2013, Chinese President Xi Jinping launched the "Belt and Road" initiative, which aims to develop and establish trade routes and economic corridors connecting more than 60 countries.

It is a development strategy that focuses on communication and cooperation between countries, especially between China, Europe and Asia, and includes two main branches: And the "Silk Road".

Through this initiative, Beijing seeks to strengthen trade and economic ties between Asia, Europe and Africa The initiative consists of two parts, one of which is called the Silk Road Economic Road, and the other is called the Maritime Silk Road of the 21st century.

The road includes corridors to Europe, the Mediterranean, the Arabian Gulf and the Indian Ocean, while the sea section includes waterways to the countries covered by the initiative.

The huge spending of the initiative is expected to benefit the global economy, with investments contributing to the economic growth of the target countries and increasing the efficiency of their infrastructure, which usually improves resource efficiency.

The overall impact of these projects depends on the costs and conditions that the target countries must meet and meet.

The initiative is heavily linked to the Chinese economy, so China is the first beneficiary of the initiative, which will be implemented by Chinese construction companies.

The most important determinants of the "Chinese belt and road strategy" in the Gulf, which are summarized as follows: 
First: energy security

China is well aware of the importance of the Arab countries to develop their economic plan as one of the most important sources of energy, and one of the largest consumer markets for Chinese goods

The projects include natural gas and oil pipeline construction, construction of road and rail networks, marine infrastructure, power lines and the Internet, reinforcing China's connectivity to the European continent

\section{Second: Economic motives}

According to some reports, China will become the biggest export market for the GCC by 2020 with a value of 142 billion US dollars and imports of 137 billion. The volume of trade between China and the GCC countries is about 279 billion dollars By 2020, and the exports of the Gulf countries to China, about 110 billion dollars, and imports by 70 billion, during the current year,

\section{Third}

China invokes the geopolitical climate of the region, which has always been characterized by instability and, according to observers, wants to avoid any potential tension in the region and at the same time maintain its interests. This is also explained by its desire to sign joint memorandums of understanding with Saudi Arabia, Kuwait and the UAE. Qatar is also a member of the Asian Investment Bank for Infrastructure

China has been close to the Arab countries, especially from the Gulf region, after acquiring the port of "Gwadar" Pakistan overlooking the Arabian Sea.

This equation makes China hold a stick from the middle, keeping its political positions from conflicts in the region swinging without taking a clear position

\section{Fourth}

Currently, nearly $90 \%$ of China's exports are transported abroad by the China-Pacific Sea, making it under the eyes of the United States because of the strong US presence in that vital region, which Beijing regards as a weakness and seeking to establish new corridors freely and also land Despite its high cost.
The new Silk Road project represents an opportunity for the Chinese to link their interests to the interests of the participating countries. China's security thus becomes an extension of their national security, which means winning new allies to support them at all levels in the face of Western powers

\section{References}

[1]. The Gulf's Position in China's "Belt and Road" Strategy Arab Jerusalem

[2]. https://www.alquds.co.uk

[3]. Arab - Chinese cooperation to revive the Silk Road Dr. Hassan Mossadeq Al Arab Newspaper

[4]. https://alarab.co.uk

[5]. Chinese Policy and the Arabian Gulf - Statement

[6]. https://www.albayan.ae

[7]. Belt and Chinese Road Initiative and the Gulf States - Al Sharq Newspaper https://www.al-sharq.com/opinion/04

[9]. Sino-Gulf Relations: From Energy to Strategic Partners Jewish Policy

[10].https://www.jewishpolicycenter.org

[11]. Invigorating Sino-Arab Relations by "One Belt and One Road" Strategy

[12]. https://www.tandfonline.com/doi/pdf/10.1080/19370679. 2014.12023254

[13]. How the Gulf row is blocking China's new Silk Road | South China

[14]. https://www.scmp.com

[15]. China's Middle East Balancing Approach - Mechanical Engineering

[16]. https://cloudfront.ualberta.ca/-/media/china/mediagallery/research/.../mena.pdf

[17]. The G.C.C. Countries and China's Belt and Road Initiative (BRI

[18]. https://www.mei.edu/.../gcc-countries-and-chinas-beltand-road-initiative-bri-curbing

[19]. Master Developers: The New Sino-Arab Gulf Visions of Economic

[20].https://www.lawfareblog.com/master-developers-newsino-arab-gulf-visions-economi ...

[21]. China and the Persian Gulf - Wilson Center

[22].https://www.wilsoncenter.org/.../ASIA\%20Program_China \%20and\%20the\%20PG.pdf

[23]. GCC and China Get Cozy on the Silk Road - Fair Observer

[24]. https://www.fairobserver.com/.../gcc-and-china-get-cozyon-the-silk-road-24010

[25]. China and the middle east: from Silk Road to Arab Spring

[26]. https://www.amazon.com/CHINA-MIDDLE-EAST-SilkSpring/dp/1857436318 